\title{
KARAKTERISTIK GAPURA DI KECAMATAN KEBAKKRAMAT KABUPATEN KARANGANYAR JAWA TENGAH (Kajian Sosial Budaya dan Ekonomi)
}

\author{
Umi Kholisya, Siska Maya, Iis Purnengsih
}

\author{
Program Studi Desain Komunikasi Visual \\ Fakultas Bahasa dan Seni, Universitas Indraprasta PGRI \\ umi_history@yahoo.com,may3110@yahoo.com,iispurningsih@gmail.com
}

\begin{abstract}
Abstrak
Gapura secara umum adalah istilah pintu untuk masuk ke masjid, candi, rumah bangsawan, keraton, desa, dan negara.Gapura sebagai suatu karya arsitektur mencerminkan ciri budaya dari kelompok manusia penciptaannya.Keanekaragaman perwujudan bangunan gapura di pulau Jawa hingga saat ini dapat disaksikan keberadaannya.Masyarakat Jawa dikenal dengan masyarakat berbudaya yang masih mempertahankan tradisinya hingga sekarang.Perwujudan bangunan gapura yang beragam tersebut dapat dilihat dari pelbagai karakteristik yang berbeda di antara bagian-bagian penyusunnya.Bagian-bagian penyusun bangunan gapura berangkat dari tatanan tradisi yang berdasarkan kepercayaan masyarakat Hindu dan Jawa.Gapura pertama yang dibangun dan menjadi cikal bakal pendirian gapura desa yang cukup populer dan fenomenal di Kabupaten Karanganyar adalah gapura Kecamatan Kebakkramat.Hubungan karakeristik gapura dengan tingkat ekonomi masyarakat desa di Kecamatan Kebakkramat Karanganyar tidak sejalan dengan tingkat perekonomian masyarakat setempat.Perekonomian yang terlihat baik di kabupaten Karanganyar namun pembangunan gapura tidak mempengaruhi banyaknya ornamen.Ditinjau dari sudut pandang teori konotasi Barthes (1957), secara denotatif gapura kecamatan Kebakkramat pada awalnya diciptakan sebagai suatu struktur bangunan utuh yang merupakan pintu masuk atau gerbang ke kawasannya.Pada tingkat berikutnya, gapura mempunyai makna konotatif, di antaranya sebagai bangunan/benda seni rupa simbol dari identitas suatu wilayah.Gapura juga merupakan benda yang berfungsi untuk mengkomunikasikan tema tertentu, tentang filosofi atau mitos-mitos yang berkembang di masyarakat dan sebagainya. Bentuk ornamen dalam setiap desain mempunyai konotasi makna tertentu, misalkan patung burung garuda dalam kepercayaan Hindu dipandang sebagai burung keramat dan sakti.
\end{abstract}

Kata Kunci : Gapura, sejarah, ekonomi, semiotika

\begin{abstract}
Gapura in general is a term the door to go to mosques, temples, manor house, palace, village and country. Gapura as an architectural masterpiece the cultural characteristics of a group of human creation. Diversity embodiment gapura building in Java until now can be watched existence. Java community is known as a civilized society that still maintains the tradition until now. Embodiment gapura diverse building can be seen from a variety of different characteristics among its constituent parts. The parts making up the building gapura departed from tradition by order of public Hindu and Javanese. The first gapura was built and became the forerunner to the establishment of the village gapura that is quite popular and is phenomenal in Karanganyar gapura Village District of Kebakkramat. Characteristic relationship gapura with the economic level of rural communities in the district of Karanganyar Kebakkramat not in line with the level of local economies. The economic level is visible both in the Karanganyar district but the construction of the gapura does not affect the number of ornaments. Viewed from the standpoint of the theory connotation of Barthes (1957), denotative gapura districts Kebakkramat was originally created as a structure intact building is the entrance or gateway to the region. At the next level, the gapura has a connotative meanings, including as building / object art symbol of the identity of a region. The gapura is also an object that serves to communicate a specific theme, about philosophy or myths that developed in the community and so forth. The Shape of ornament in any design connotations specific meaning, example eagle statue in Hindu belief is seen as sacred and powerful bird.
\end{abstract}

Keywords: Gapura, history, economics, semiotics 


\section{PENDAHULUAN}

Gapura berasal dari bahasa Sansekerta, yaitu "Gopura" yang berarti pintu gerbang (Singgih, 2013), serta pada hakekatnya perwujudan bangunan gapura terdiri dari dua tipe, yaitu Gapura Paduraksa dan Gapura Bentar (Widyosiswoyo, 2000: 123).

Keanekaragaman perwujudan bangunan gapura di Pulau Jawa hingga saat ini dapatdisaksikan keberadaannya. Masyarakat Jawa dikenal dengan masyarakat berbudaya yang masih mempertahankan tradisinya hingga sekarang. Perwujudan bangunan gapura yang beragam tersebut dapat dilihat dari pelbagai karakteristik yang berbeda di antara bagian-bagian penyusunnya. Bagian-bagian penyusun bangunan gapura berangkat dari tatanan tradisi yang berdasarkan adat dan kepercayaan masyarakat Bali.

Seiring dengan perkembangan jaman, masyarakat selalu berupaya untuk selalu beradaptasi untuk bertahan hidup. Berkaitan dengan adaptasi, masyarakat Jawa memiliki sikap yang lentur sekaligus mampu mengembangkan lebih jauh kebutuhan mereka. Sebagai dampak dari adaptasi, maka tidak terelakkan terjadinya perubahan dalam bangunan gapura di Pulau Jawa khususnya di Kabupaten Karanganyar. Perubahan muncul dari perkembangan pola pikir dan inovasi baru, yang disertai dengan perkembangan dalam bidang sosial, ekonomi dan budaya. Perubahan dapat terjadi dalam aspek fisik maupun nonfisik, perubahan sistem budaya mempengaruhi sistem sosial dan sistem ekonomi.

Gapura dapat dikatakan sebagai bentuk ekspresi yang terkait dengan status sosial suatu masyarakat. Karakteristik gapura secara visual dibentuk dari unsur-unsur visual berupa ornamen-ornamen tradisi Jawa.

\section{METODE PENELITIAN}

Pendekatan yang digunakan dalam penelitian ini adalah pendekatan metodologis dan teoritis. Metodologis yang digunakan yaitu deskriptif kualitatif. Deskriptif kulalitatif digunakan untuk menjelaskan dan mengungkapkan makna visualisasi gapura. Teori yang digunakan untuk menggabungkan makna dan budaya yaitu menggunakan kajian semiotika.

Data merupkan segala fakta dan angka yang diperoleh dari informasi. Dalam hal ini yaitu data mengenai karakteristik gapura-gapura desa di Kecamatan Kebakkramat Kabupaten Karanganyar. Sumber data yang digunakan yaitu primer dan sekunder. Sumber data primer diperoleh dari wawancara dengan narasumber yaitu tokoh masyarakat dan warga masyarakat sekitar desa di Kecmatan Kebakkramat Kabupaten Karanganyar. Sedangkan, sumber data sekunder diperoleh dari buku-buku dan data dari dinas terkait.

Metode yang digunakan adalah metode wawancara dan studi pustaka. Metode wawancara untuk mendapatkan informasi dilakukan dengan mengajukan pertanyaan kepada narasumber berkaitan dengan karakteristik gapura-gapura desa di Kecamatan Kebakkramat Kabupaten Karanganyar. Sedangkan studi pustaka dilakukan dengan mencari referensi yang berkaitan dengan topik yang sedang dibahas.

\section{Sejarah Pembangunan Gapura Desa Kecamatan Kebakkramat \\ Kabupaten Karanganyar}

Candi merupakan pengetahuan dasar seni bangunan gapura, yaitu bangunan yang berada pada jalan masuk ke atau keluar dari suatu tempat, lahan, atau wilayah menurut Kitab Manasara (perpusnas.go.id). Gapura sendiri bisa berfungsi sebagai petunjuk batas wilayah 
atau sebagai pintu keluar masuk yang terletak pada dinding pembatas sebuah komplek bangunan tertentuGapura berfungsi sebagai petunjuk batas wilayah atau pintu keluar-masuk yang terletak pada dinding pembatas sebuah kompleks bangunan (Wardana, 2008: 7). Gapura mempunyai fungsi penting dalam sebuah kompleks bangunan, sehingga gapura juga nencerminkan keagungan dari bangunan yang dibatasinya. Perbedaan kedua bangunan tersebut terletak pada ruangannya. Candi mempunyai ruangan yang tertutup, sedangkan ruangan dalam gapura merupakan lorong yang berfungsi sebagai jalan keluar-masuk.Dari segi fungsi dan arsitekturnya, di Bali dikenal adanya pintu yang disebut candi bentar, paduraksa dan bebetelan (widyosiswoyo, 2007: 191).

Pada saat masuknya Islam ke Indonesia. Bangunan gapura disesuaikan dengan kebutuhan dan adat istiadat masyarakat yang menganut ajaran Islam. Pada masa Islam gapura identik dengan bangunan makam.Gapura dapat diartikan sebagai pintu pertobatan, berasal dari bahasa Arab yang maknanya "pengampunan". Pada hakekatnya perwujudan bangunan gapura terdiri dari dua tipe, yaitu paduraksa dan bentar (Widyosiswoyo, 2007: 123).

Gapura secara umum sebagai istilah pintu untuk masuk masjid, candi, rumah bangsawan, keraton, desa, dan negara.Gapura sebagai suatu karya arsitektur mencerminkan ciri budaya dari kelompok manusia penciptaannya. Ada dua corak gapura yang berasal dari Candi Hindu, yaitu corak gapura yang bagian atasnya tertutup dengan susunan atap jenjang, jadi semacam gapura paduraksa di bangunan pura Bali atau yang disebut kori agung di Jawa, dan corak gapura yang terbuka bagian atasnya yang menyerupai candi bentar yang disebut gapura belah (Yudoseputro, 2008:162).
Candi bentar memiliki beragam keunikan yang sampai sekarang belum terungkap dan belum banyak dikenal oleh masyarakat. Candi bentar memiliki makna dan fungsi yang berbeda-beda pada setiap massanya. Candi bentar atau gapura adalah pintu gerbang yang bentuknya terbelah dua. Dalam sejarah perkembangannya candi bentar awalnya merupakan sebuah candi dengan denah empat persegi dan fungsinya sebagai jalan keluar masuk. Candi bentar sudah dikenal zaman Majapahit, peninggalannya berupa Wringin Lawang tetapi tidak dilengkapi dengan ornamentasi. Model pintu gerbang yang disebut candi bentar ini banyak dipakai di daerah Jawa, khususnya di Jawa Timur. Gapura bentar ini dijadikan model sebagai pintu gerbang masuk desa.Di Jawa Tengah model ini juga terdapat di Candi Ceto Kecamatan Ngargoyoso. Budaya Majapahit ini banyak juga digunakan sebagai gerbang makam seperti di Bayat, Kabupaten Klaten, bahkan di Cirebon digunakan sebagai pintu masuk masjid (Widyosiswoyo, 2007: 192).

Pada saat masuknya Islam ke Indonesia. Bangunan gapura disesuaikan dengan kebutuhan dan adat istiadat masyarakat yang menganut ajaran Islam. Pada masa Islam gapura identik dengan bangunan makam. Gapura dapat diartikan sebagai pintu pertobatan, berasal dari bahasa Arab yang maknanya "pengampunan". Pada hakekatnya perwujudan bangunan gapura terdiri dari dua tipe, yaitu paduraksa dan bentar (Widyosiswoyo, 2007: 123).

Gapura secara umum sebagai istilah pintu untuk masuk masjid, candi, rumah bangsawan, keraton, desa, dan negara. Gapura sebagai suatu karya arsitektur mencerminkan ciri budaya dari kelompok manusia penciptaannya. Ada dua corak gapura yang berasal dari Candi Hindu, yaitu corak gapura yang bagian atasnya tertutup dengan susunan atap 
jenjang, jadi semacam gapura paduraksa di bangunan pura Bali atau yang disebut kori agung di Jawa, dan corak gapura yang terbuka bagian atasnya yang menyerupai candi bentar yang disebut gapura belah (Yudoseputro, 2008:162).

Candi bentar memiliki beragam keunikan yang sampai sekarang belum terungkap dan belum banyak dikenal oleh masyarakat. Candi bentar memiliki makna dan fungsi yang berbeda-beda pada setiap massanya. Candi bentar atau gapura adalah pintu gerbang yang bentuknya terbelah dua. Dalam sejarah perkembangannya candi bentar awalnya merupakan sebuah candi dengan denah empat persegi dan fungsinya sebagai jalan keluar masuk. Candi bentar sudah dikenal zaman Majapahit, peninggalannya berupa Wringin Lawang tetapi tidak dilengkapi dengan ornamentasi. Model pintu gerbang yang disebut candi bentar ini banyak dipakai di daerah Jawa, khususnya di Jawa Timur. Gapura bentar ini dijadikan model sebagai pintu gerbang masuk desa. Di Jawa Tengah model ini juga terdapat di Candi Ceto Kecamatan Ngargoyoso. Budaya Majapahit ini banyak juga digunakan sebagai gerbang makam seperti di Bayat, Kabupaten Klaten, bahkan di Cirebon digunakan sebagai pintu masuk masjid (Widyosiswoyo, 2007: 192).

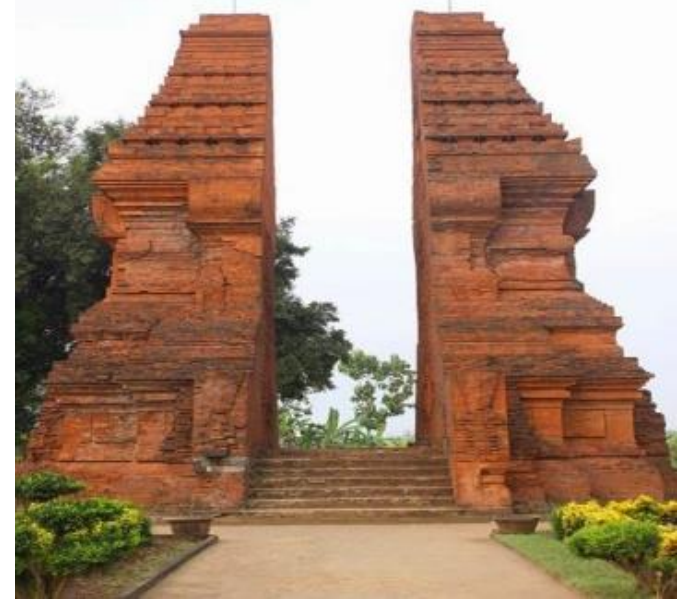

Gambar 1. Candi Wringin Lawang,

Mojokerto.Berbentuk Candi Bentar(Sumber: http://afeministblog.blogspot.co.id/)
Jenis pintu gerbang lainnya adalah paduraksa. Fungsinya adalah pintu pemisah halaman depan dengan tengah atau belakang. Perbedaan yang mencolok antara candi bentar dan paduraksa terdapat pada bagian atapnya.Pada bagian candi bentar bagian atapnya tidak bertemu atau tanpa atap, sedangkan paduraksa bagian atap bertemu dan menjadi atap. Terjadinya paduraksa pada perkembangannya hampir sama dengan candi bentar yaitu sebagai candi biasa, kemudian karena berfungsi untuk jalan pada bagian lorongnya maka dinding belakangnya dibuka, tetapi bagian atasnya tetap dipertahankan.

Pada masa Majapahit salah satu peninggalan paduraksa adalah candi Bajangratu. Pada bentuk fisik candi Bajangratu kaki bangunan dibuat cukup tinggi sehingga diperlukan anak tangga.Selain itu badan bangunan yang ramping dapat diterobos yang berfungsi sebagai pintu.Atapnya yang tinggi berpadu dengan puncaknya yang datar memberikan langgam khas candi Jawa Timuran.Pada masa Islam bentuk ini masih dipergunakan sebagai pintu makam atau masjid seperti pada makam Sendang Duwur di Lamongan.

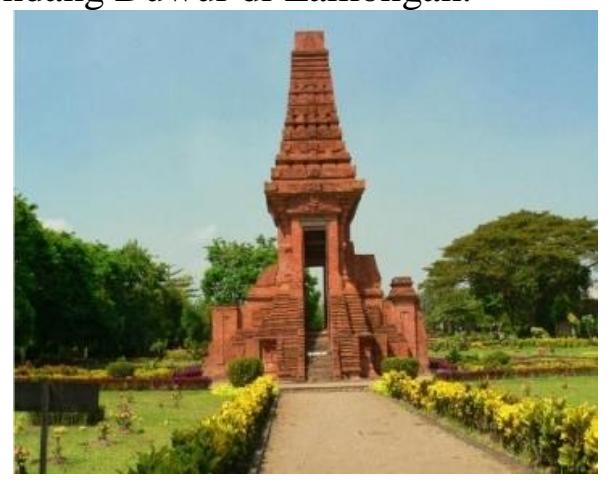

Gambar 2. Candi Bajang Ratu,

Mojokerto.Berbentuk Paduraksa

(Sumber:www.putrimuqodimatul.blogspot.co.id)

Candi Bentar dan Paduraksa di daerah Bali dapat dijumpai pada berbagai banguna pura seperti Uluwatu da Taman Ayun.Pada umumnya paduraksa disebut juga kori agung (pintu utama) yang 
digunakan atau dibuka jika ada upacara saja dan ditutup pada hari biasa. Sedangkan untuk pintu sehari-hari digunakan pintu yang disebut bebetelan atau pemedelan yang letaknya di kiri dan kanan paduraksa.Bangunan bebetelan mempunyai bentuk yang lebih sederhana dibandingkan dengan candi bentar dan paduraksa.

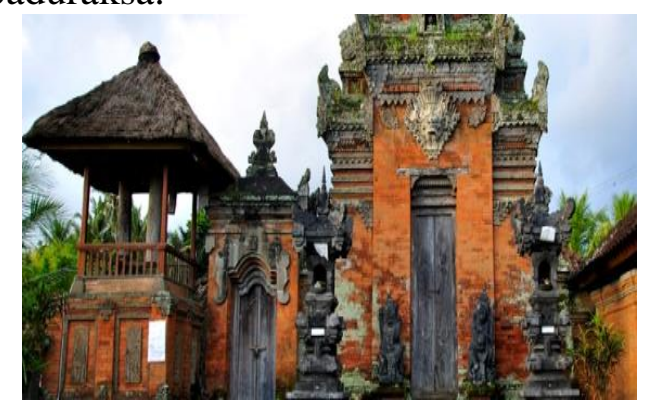

Gambar 3.Salah satu contoh Kori Agung di Bali(sebelah kanan) dan bebetelan (kiri)(sumber: http://www.pedharmanaryasukahet.org/)

Gapura selamat datang di desadesa kabupaten Karanganyar menjadi populer beberapa tahun belakangan. Menurut beberapa narasumber yang diwawancarai bahwa pembangunan gapura-gapura desa mulai menjadi populer pada saat kepemimpinan bupati Hj. Rina Iriani Sri Ratnaningsih, S.Pd., M. Hum. Wanita yang pernah bekerja sebagai guru sekolah dasar ini menjabat sebagai bupati Karanganyar para periode 2003-2008 dan mengundurkan diri dari jabatan karena mencalonkan diri untuk kedua kali sebagai bupati kabupaten tersebut pada 17 Juli 2008. Menurut Bapak Samidi tokoh masyarakat di daerah Gedangan Kecamatan Kebakkramat bahwa gapura di daerah Gedangan merupakan cikal bakal pembangunan gapura desa termegah di Kabupaten Karanganyar yang diresmikan langsung oleh Bupati Rina.

Dalam proposal resmi warga Desa Gedangan disebutkan:

"Pada tahun 2005, tepatnya tanggal 16 agustus 2005 Warga RW II Pawisman Gedangan telah berhasil membangun gapura disebelah utara. Gapura tersebut dinamai dengan
"Manunggaling Karsa Gotro Wiworo". Gapura yang dibangun tersebut juga diresmikan oleh Bupati Karanganyar $\mathrm{Hj}$ Rina Iriani Sri Ratnaningsih S.Pd, M.Hum. Karena bentuk dan nilai seni dari gapura tersebut juga telah merih juara I lomba gapura untuk kategori umum yang dieselenggarakan oleh TA TV Solo, dan juara II yang diselenggarakan oleh Harian Solo Pos".

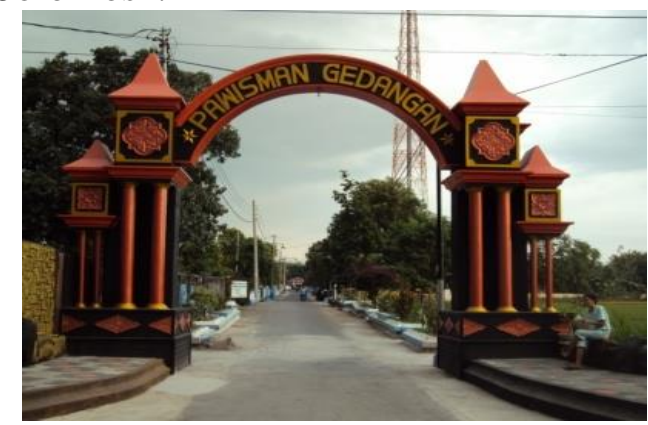

Gambar 4. Gapura desa pertama yang megah di Kecamatan KebakkramatKabupaten Karanganyar(Sumber: dokumentasi Desa Gedangan Kemiri)

Setelah dibangunnya gapura tersebut dikatakan oleh Pak Budi seorang guru sejarah SMA Negeri I Kebakkramat yang tinggal di kawasan tersebut bahwa desa-desa tetangga mulai mengikuti jejak Desa Gedangan untuk membangun gapura di desa mereka. Hal senada juga diungkapkan Bapak Samidi, tokoh masyarakat di Desa Gedangan Kecamatan Kebakkramat Karanganyar bahwa pembangunan gapura-gapura desa memang dimulai pada masa kepemimpinan Bupati Rina. Berdasarkan hasil wawancara beberapa narasumber yang disebutkan di atas, tidak ada instruksi khusus untuk membangun infrastruktur berupa gapura, ide tersebut murni dari warga yang didukung oleh pemerintahan saat itu. Dukungan tersebut direalisasikan dalam bentuk dana bantuan pemerintah maupun kebijakan pemerintah serta sikap pemerintah yang meresmikan gapura yang telah dibangun oleh masyarakat sebagai bentuk apresiasi kepada warga masyarakat. 


\section{Hubungan Karakteristik Gapura dengan Tingkat Sosial Ekonomi Masyarakat Desa di Kecamatan Kebakkramat Kabupaten Karanganyar.}

Kebakkramat adalah suatu wilayah kecamatan di Karanganyar yang memiliki banyak gapura dengan karakteristik yang unik, menarik dan megah.. Banyak yang berpendapat bahwa kemegahan gapura di kecamatan Kebakkramat dipengaruhi oleh tingkat sosial ekonomi masyarakatnya. Untuk lebih jelas mengetahui kondisi sosial ekonomi masyarakat kecamatan Kebakkramat, pada penelitian ini kami berhasil mendapatkan data kesejahteraan masyarakat Kebakkramat yang diukur melalui tingkat pendidikan, mata pencaharian, dan kesejahteraan penduduknya.

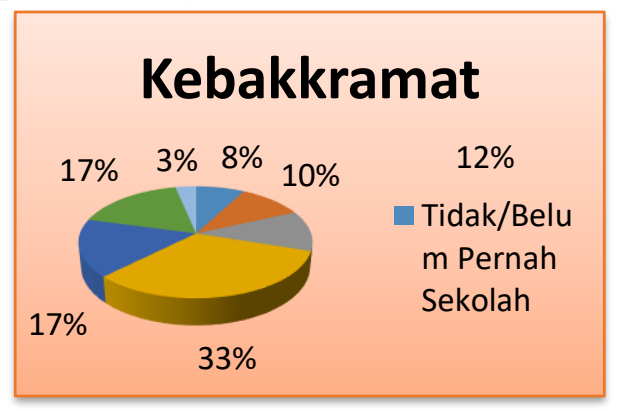

Gambar 5. Tingkat Pendidikan Kebakkramat Tahun 2010

Kecamatan

kebakkramat mayoritas masih memiliki tingkat pendidikan SD/MI yaitu sebesar 33 persen. Jika di lihat dari desain gapura yang ada di kebakkramat, maka bisa dikatakan tingkat pendidikan belum memiliki pengaruh yang berarti. Artinya kecamatan kebakkramat yang memiliki tingkat pendidikan yang mayoritas masih SD dapat membuat atau memiliki gapura dengan kreasi ornamen yang baik

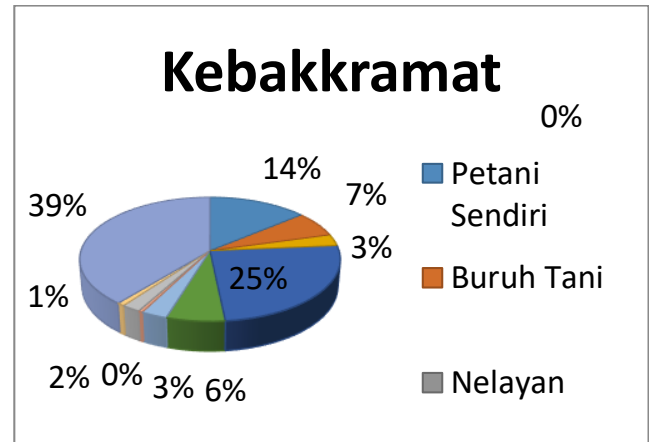

Gambar 6. Mata pencaharian kecamatan kebakkramat tahun 2010

Sebagian besar masyarakat di kecamatan kebakkramat mempunyai mata pencaharian buruh industri. Kemudian sebagian ada yang mempunyai mata pencaharian di sektor pertanian (petani sendiri atau buruh tani). Hal ini sesuai dengan kondisi alam kecamatan kebak kramat yang pegunungan. Selebihnya masyarakat kecamatan kebakkramat bekerja sebagai pengusaha, disektor pengangkutan, PNS/TNI/Polri, pensiumam jasa-jasa dan lain lain.

Mata pencaharian petani sangat bergantung kepada kondisi alam. Pendapatan yang di dapat dari seorang petani tidak selalu pasti nominalnya setiap bulan. Jika dibandingkan dengan masyarakat yang memiliki mata pencaharian sebagai PNS/TNI/Polri yang memiliki pendapatan tetap setiap bulannya. Hal ini tidak membuat surut minat masyarakat dalam pembangunan gapura. Pembangunan gapura yang memiliki ornamen yang banyak di dapatkan dari swadaya masyarat dan juga iuran warga. Semangat gotong royong dan kekeluargaan yang mewujudkan pembangunan gapura yang berdiri dikecamatan kebak kramat. Pembangunan gapura dilakukan secara swadaya masyarakat yang memiliki arti bahwa pembangunan tidak menggunakan jasa pertukanngan. 


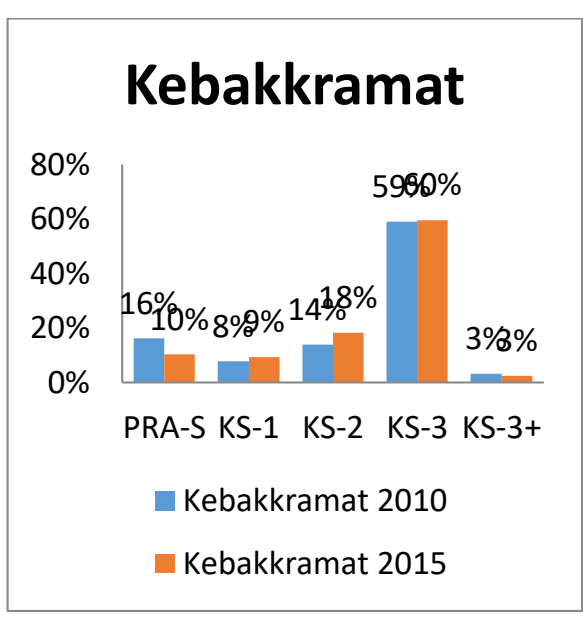

Gambar 7. Tingkat kesejahteraan kecamatan kebak kramat tahun 2010 dan 2015

Jika dilihat dari tingkat kesejateraannya pada tahun 2010 ke 2015 mayoritas penduduk kecamatan kebak kramat dikategori tingkat kesejahteraan keluarga sejahtera 3 mengalami peningkatan pada kecamatan kebakkramat sebesar 1 persen. Menurut BKKBN 2009 keluarga sejahtera 3 adalah keluarga yang telah memenuhi seluruh kebutuhan dasar, sosial psikologis dan kebutuhan pengembangannya. Namun pada tahapan keluarga sejahtera 3 belum dapat memberikan sumbangan yang maksimal terhadap masyarakat seperti secara teratur memberikan sumbangan dalam bentuk material dan keuangan untuk kepentingan sosial kemasyarakatan serta berperan aktif dengan menjadi pengurus lembaga kemasyarakatan atau yayasan-yayasan sosial, keagamaan, kesenian, olahraga, pendidikan dan sebagainya.

\section{Karakteristik Bentuk Pemaknaan Visual Gapura-Gapura Desa di Kecamatan Kebakkramat Kabupaten Karanganyar}

Dari beberapa jenis gapura yang kami teliti di kecamatan Kebakkramat, terdapat 3 sampel gapura yang menarik untuk diteliti terutama dari sudut pandang semiotika. 3 sampel gapura-gapura tersebut antara lain :

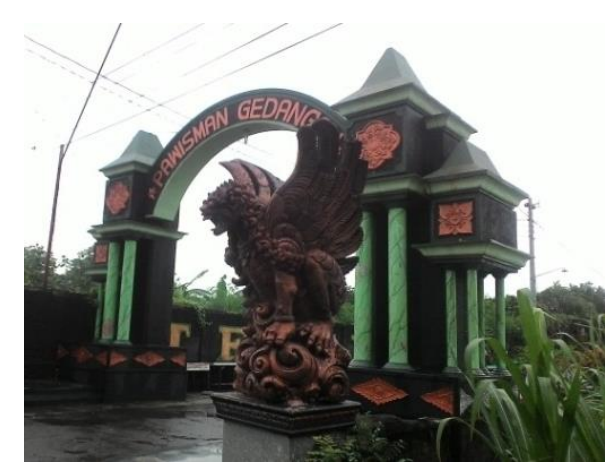

Gambar 8. Gapura PawismanGedangan (sumber: dokumentasi peneliti)

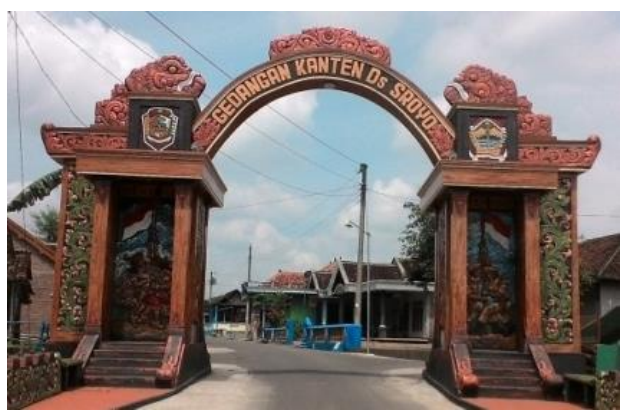

Gambar 9. Gedangan Kanten Ds. Sroyo (sumber: dokumentasi peneliti)

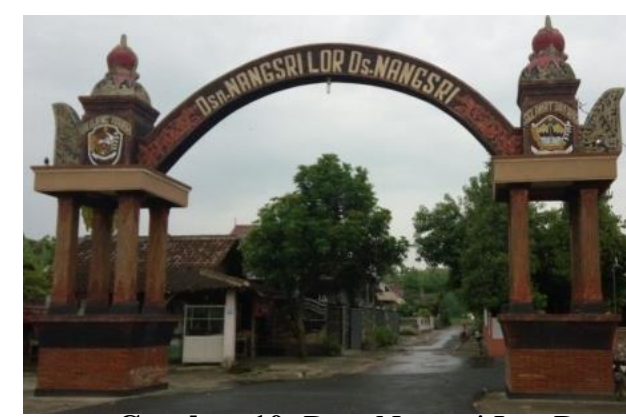

Gambar 10. Dsn. Nangsri Lor Ds.

Nangsri(sumber: dokumentasi peneliti)

Dalam membangun kontstruksi pemaknaan pada gapura, penelitian ini menggunakan teori semiotika yang dikembangkan oleh Roland Barthes. Piliang dalam Christomy dan Yuwono (2010: 94) menjelaskan bahwa hubungan antara penanda dan petanda bukanlah terbentuk secara alamiah, melainkan hubungan yang terbentuk berdasarkan konvensi, maka sebuah penanda pada dasarnya membuka pelbagai peluang petanda dan makna. Roland Barthes mengembangkan dua tingkatan pertandaan yang memungkinkan untuk dihasilkannya makna yang juga 
bertingkat-tingkat, yaitu tingkat denotasi dan konotasi. Denotasi, adalah tingkat pertandaan yang menjelaskan hubungan antara penanda dan petanda, atau antara tanda dan rujukannya pada realitas, yang menghasilkan makna yang eksplisit, langsung dan pasti. Konotasi adalah tingkat pertandaan yang menjelaskan hubungan antara penanda dan petanda, yang di dalamnya beroperasi makna yang tidak eksplisit, tidak langsung dan tidak pasti. Ia menciptakan makna lapis kedua, yang terbentuk ketika penanda dikaitkan dengan pelbagai aspek psikologis, seperti perasaan, emosi atau keyakinan (Piliang dalam Christomy dan Yuwono, 2010: 94). Selain itu, Barthes juga melihat makna yang lebih dalam tingkatnya, tetapi lebih bersifat konvensional, yaitu

makna yang berkaitan dengan mitos. Mitos dalam pemahaman semiotika Barthes adalah pengkodean makna dan nilai-nilai sosial (yang sebetulnya arbiter atau konotatif) sebagai sesuatu yang dianggap alamiah. Pelbagai tingkatan pertandaan ini sangat penting dalam penelitian desain, karena dapat digunakan sebagai model dalam membongkar makna desain (iklan, produk, interior, fesyen) yang berkaitan secara implisit dengan nilai-nilai ideologi, budaya, moral, spiritual (Piliang dalam Christomy dan Yuwono, 2010:94-95).

Untuk mengetahui karakteristik dan elemen-elemen yang terdapat pada 3 sampel gapura di kecamatan Kebakkramat dapat dilihat dari tabel analisis adalah sebagai berikut :

\begin{tabular}{|c|c|c|c|}
\hline $\begin{array}{l}\text { Sampel } \\
\text { Gapura }\end{array}$ & Analisis visual & $\begin{array}{c}\text { Analisis } \\
\text { Warna }\end{array}$ & Analisis Font \\
\hline $\begin{array}{l}\text { Pawisman } \\
\text { Gedangan }\end{array}$ & $\begin{array}{ll} & \text { Ornamen Garuda } \\
\circ & \text { Atap Rumah Joglo } \\
\circ & \text { Ornamen motif Sulur } \\
\circ & \text { Lingga yoni }\end{array}$ & $\begin{array}{ll}\circ & \text { Hitam } \\
\circ & \text { Hijau } \\
\circ & \text { merah }\end{array}$ & $\begin{array}{l}\text { Teks : Pawisman Gedangan } \\
\text { huruf uppercase atau huruf } \\
\text { besar semua }\end{array}$ \\
\hline $\begin{array}{l}\text { Dsn. } \\
\text { Nangsri } \\
\text { Lor Ds } \\
\text { Nangsri }\end{array}$ & $\begin{array}{ll} & \text { Makhuta, } \\
\circ & \text { Lar (sayap) } \\
\circ & \text { motif sulur } \\
\circ & \text { lingga yoni }\end{array}$ & $\begin{array}{ll}\circ & \text { emas } \\
\circ & \text { Hitam } \\
\circ & \text { merah }\end{array}$ & $\begin{array}{l}\text { Teks : Dsn. Nangsri Lor Ds } \\
\text { Nangsri, huruf uppercase atau } \\
\text { huruf besar semua }\end{array}$ \\
\hline $\begin{array}{l}\text { Gedangan } \\
\text { kanten Ds. } \\
\text { Sroyo }\end{array}$ & $\begin{array}{ll}\circ & \text { Garuda } \\
\circ & \text { Motif Sulur } \\
\circ & \text { Gulungan } \\
\circ & \text { Motif hias manusia } \\
\circ & \text { Lingga Yoni } \\
\end{array}$ & $\begin{array}{ll}\circ & \text { Hitam } \\
\circ & \text { Hijau } \\
\circ & \text { merah }\end{array}$ & $\begin{array}{l}\text { Teks : Gedangan kanten Ds. } \\
\text { Sroyo,huruf uppercase atau } \\
\text { huruf besar semua }\end{array}$ \\
\hline
\end{tabular}

Dari 3 sampel gapura yang diteliti dapat dilihat bentuk karakteristik yang terdapat pada gapura-gapura yang tersebar di kecamatan Kebakkramat. Hampir semua gapura dalam tampilannya selalu menggunakan ornamen-ornamen motif hias seperti Naga, Garuda, Lar, Makhuta, atap rumah Joglo, gunungan atau motif naga.

Motif naga termasuk ular merupakan binatang yang paling utama sebagai lambang dunia bawah. Dalam kisah pengadukan lautan susu Samoedra
Montana untuk mencari air amrta bagi para dewa agar dapat hidup abadi, seekor naga berjasa dengan melilitkan tubuhnya ke gunung Mahameru yang kemudian diputar-putar ke dalam Samoedra Montana. Karena itu naga dalam kepercayaan melambangkan air, kesuburan, dan kesaktian.

Motif Sulur dipakai untuk menamakan motif hias tumbuhtumbuhan yang diubah dengan bentuk dasar lengkung pilin tegar dan juga bagian batang yang menjalar dan 
menyerupai spiral. Pada masyarakat Jawa motif ini dipercaya sebagai lambang kebahagiaan, kemujuran dan harapan masa depan yang lebih baik.

Motif burung Garuda dalam epos Mahabharata dan Ramayana (dunia wayang) burung garuda sangat terkenal. Garuda sebagai burung yang mirip burung rajawali hanya ada dalam mitos. Dalam kepercayaan Hindu, garuda merupakan kendaraan Wisnu, karena itu garuda dipandang sebagai burung keramat dan sakti. Sayap pada Garuda (lar) melambangkan keluhuran. Burung Garuda adalah burung yang penuh percaya diri, energik dan dinamis serta pantang menyerah. Ia terbang menguasai angkasa dan memantau keadaan sendiri, tak suka bergantung pada yang lain. Garuda yang merupakan lambang pemberani dalam mempertahankan wilayah, tetapi dia pun akan menghormati wilayah milik yang lain sekalipun wilayah itu milik burung yang lebih kecil.

Atap rumah Joglo, berdasarkan pada pandangan hidup orang Jawa bahwa kehidupan manusia tidak terlepas dari pengaruh alam semesta, atau dalam lingkup yang lebih terbatas adalah dari pengaruh lingkungan sekitarnya, maka keberadaan rumah bagi orang Jawa harus mempertimbangkan hubungan tersebut. Joglo sebagai salah satu simbol kebudayaan masyarakat Jawa, merupakan media perantara untuk menyatu dengan Tuhan (kekuatan Ilahi) sebagai tujuan akhir kehidupan (sangkan paraning dumadi), berdasar pada kedudukan manusia sebagai seorang individu, anggota keluarga dan anggota masyarakat. Nilai filosofis Joglo merepresentasikan etika Jawa yang menuntut setiap orang Jawa untuk memiliki sikap batin yang tepat, melakukan tindakan yang tepat, mengetahui tempat yang tepat (dapat menempatkan diri) dan memiliki pengertian yang tepat dalam kehidupan.
Dalam budaya Jawa rumah dengan Joglo melambangkan prestise.

Lingga Yoni adalah lambang alat vital laki (Lingga) dan alat vital wanita (Yoni) atau proses penciptaan manusia. Sejak jaman dahulu Lingga Yoni dijadikan pusat pemujaan kepada Tuhan. Lingga Yoni merupakan simbol penciptaann manusia dan dianggap sesuatu yang sangat sakral. Lingga Yoni oleh kalangan tertentu dianggap juga sebagai Lambang Kemakmuran. Kemakmuran manusia itu disebabkan karena mampu mensakralkan dan mensucikan Lingga Yoni. Lingga dilambangkan dengan tiang atau tonggak, bisa berbentuk persegi atau silinder. Yoni dilambangkan sebuah wadah yang berbentuk persegi atau lingkaran yang memiliki pancuran.

Makutha (mahkota) yaitu sebagai simbol raja dan sebagai simbol kebudayaan Jawa. Oleh karena itu, siapa saja yang memakai atau menerima gambar mahkota selayaknya berjiwa budaya Jawa. Dalam arti bahwa jiwa budaya Jawa memberi tuntunan, budaya sebagai uwoh pangolahing budi secara lahir dan batin berdasarkan budi luhur dan keutamaan. Pakarti lahir harus seiring dengan pakarti batin, hal yang demikian mencerminkan adanya sifat keharmonisan dalam budaya Jawa..

Gunungan Blumbangan Surakarta diciptakan oleh Sunan Kalijaga pada tahun 1521. Merupakan simbol kehidupan, setiap gambar yang ada didalamnya melambangkan seluruh alam raya beserta isinya, mulai dari manusia sampai dengan hewan serta hutan dan kelengkapannya. Bentuk gunungan meruncing keatas melambangkan bahwa hidup manusia didunia ini menuju yang di atas yaitu Alloh SWT. Digunakan antara lain untuk membuka dan menutup pentas wayang.

Ditinjau dari segi warna, warnawarna yang digunakan pada 3 sampel 
gapura adalah warna alam yaitu hitam, merah tembaga, hijau. Dalam budaya Jawa warna-warna tersebut merupakan simbol kasepuhan (yang dianggap tua). Sifat kasepuhan ini terlihat dalam bentuk lahir dan batin, yang mencerminkan sabar, tidak terburu nafsu dan sejenisnya. Hal ini memiliki makna filosofis bahwa seseorang raja harus memiliki jiwa kasepuhan.

Teks pada gapura selalu menggunakan huruf besar semua atau kapital semua (uppercase). Tipe huruf ini memiliki karakter yang mudah dibaca dan memberi kesan dominan karena diletakkan pada latar depan. Peran teks dalam mendukung pesan yang ingin disampaikan sangatlah penting, yaitu untuk membatasi supaya makna tidak berkembang liar ke mana-mana. Barthes $(1977,38)$ memperkenalkan konsep anchorage untuk elemen linguistik berupa tulisan. Menurutnya, "at the level mass communications, it appears that the linguistic message is indeed present in every image: as title, caption, accompanying press article, film dialogue, comic strip balloon." (pada tingkat komunikasi masa, tampak bahwa pesan linguistik hadir dalam setiap gambar: sebagai judul, keterangan, yang menyertai artikel pers, dialog film, balon kata komik). Teks pada 3 sampel gapura dengan menggunakan huruf uppercase, atau huruf kapital semua, memberi kesan dominan karena diletakkan pada latar depan. untuk menonjolkan identitas wilayahnya.

Dari penjelasan tabel dan analisis di atas dapat disimpulkan bahwa :

Pemaknaan denotatif pada gapura adalah ornamen-ornamen motif hias merepresentasikan simbol-simbol budaya Hindu dan Jawa yang merupakan kesatuan elemen-elemen dalam 3 sampel gapura, seperti ornamen motif hias: garuda, naga, motif sulur, motif hias manusia, Lingga yoni, atap rumah Joglo, atau gunungan/blumbangan.

Makna konotatif bersifat subjektif dalam pengertian bahwa ada pergeseran dari makna umum (denotatif) karena sudah ada penambahan nilai tertentu. Pemaknaan tingkat konotatif hanya terdapat dalam semiotika Roland Barthes. Dalam 3 sampel gapura, sudah diperoleh hasil analisis berupa identifikasi tanda dari beberapa aspek penanda dan petanda yang diteliti. Pada 3 sampel gapura menyiratkan kesejahteraan. Dikatakan sejahtera karena pada pemaknaan konotasi pada 3 sampel gapura terdapat berbagai elemen menunjukkan ornamen motif hias sebagai perlambang kesejahteraan masyarakat seperti kesuburan, kebahagiaan, keharmonisan, dan kemujuran. Ditinjau dari segi warna, yang digunakan adalah warna yang bermakna kasepuhan. Dan penggunaan tipe huruf yang sama yaitu uppercase, memberi kesan dominan karena diletakkan pada latar depan untuk menonjolkan identitas wilayah. Keseluruhan elemen-elemen pada 3 sampel gapura tersebut merujuk kepada nilai prestise.

Pemaknaan mitos pada 3 sampel gapura adalah mitos perbedaan dalam nilai prestise. Prestise menunjukkan diferensiasi dan stratifikasi di dalam tatanan masyarakat. Elemen-elemen berupa ornamen motif hias yang merepresentasikan simbol-simbol budaya Hindu dan Jawa, ini menunjukkan nilai perbedaan dan kelas didalamnya.

Dari kesimpulan 3 sampel tersebut menyimbolkan sesuatu, yaitu nilai prestise. Dimana ketiga sampel gapura tersebut menyimbolkan perbedaan yang merupakan hal yang ingin dicapai oleh nilai prestise. 


\section{SIMPULAN}

Sejarah gapura di Indonesia diawali pada masa kerajaan Majapahit dengan ditemukannya bangunan gapura yang dinamakan Candi Wringin Lawang yang berbentuk bentar dan Candi Bajang Ratu yang berbentuk paduraksa. Pada masa itu candi bentar adalah pintu gerbang untuk memasuki halaman paling profane. Bentuk ini tetap bertahan hingga masa Islam. Sejarah pembangunan gapura desa dimulai pada masa pemerintahan Bupati $\mathrm{Hj}$. Rina Iriani Sri Ratnaningsih, S.Pd., M. Hum pada dua periode kepemimpinan dari tahun 20032008 dan 2008-2013. Gapura pertama yang dibangun dan menjadi cikal bakal pendirian gapura desa yang cukup populer dan fenomenal di Kabupaten Karanganyar adalah gapura Desa Gedangan Kemiri Kecamatan Kebakkramat.

Hubungan karakeristik gapura dengan tingkat ekonomi masyarakat desa di Kabupaten Karanganyar tidak sejalan dengan tingkat perekonomian masyarakat setempat. Perekonomian yang terlihat adalah baik di kabupaten Karanganyar namun pembangunan gapura dengan tidak banyaknya ornamen. Sedangkan Kabupaten Jaten yang perekonomian tidak terlalu baik diantara lima kabupaten memiliki pembangunan gapura dengan banyak ornamen. Pembangunan gapura juga di dukung dengan tingkat sosial yang baik. Hal ini tercermin dari pembangunan gapura dengan dana swadaya masyarakat dan dikerjakan oleh warga setempat.

Memiliki gapura yang megah adalah suatu kebanggaan bagi masyarakat di Karanganyar, sebab itu masyarakat akan melakukan apapun bagi pembangunannya, seperti gotongroyong bahkan dana yang dikeluarkan. Jadi, karakteristik gapura tidak mempengaruhi seberapa banyak dana yang dikeluarkan.mitos perbedaan dalam nilai prestise. Prestise menunjukkan diferensiasi dan stratifikasi di dalam tatanan masyarakat.

\section{DAFTAR PUSTAKA}

Budiman, M. (2010). "Semiotika dalam Tafsir Sastra: Antara Riffaterre dan Barthes," dalam buku Semiotika Budaya. Penyunting Christomy, T. dan Yuwono, U. Jakarta: Pusat Penelitian Kemasyarakatan dan Budaya Fakultas Ilmu Pengetahuan dan Budaya Universitas Indonesia

Hoed, B. H. (2011). Semiotika dan Dinamika Sosial Budaya. Jakarta: KomunitasBambu.

Singgih, A. (2003). Pengaruh Faktor Sosial Budaya Terhadap Bentuk Dan Tata Ruang Masud Makam Menara Kudus. Masters thesis, Program Pascasarjana Universitas Diponegoro.

Sunaryo, A. (2009). Ornamen Nusantara. Kajian Khusus tentang Ornamen Nusantara. Semarang: Dahara Prize.

Widyosiswoyo, S. (2006). Sejarah Seni Rupa Indonesia. Jakarta: Penerbit: Trisakti.

Yudoseputro, W. (2008). Jejak-Jejak Tradisi Bahasa Rupa Indonesia Lama. Jakarta: Yayasan Seni Visual Indonesia

Wardana, A. (2008). Gapura Untuk Rumah Tinggal. Semarang: Griya Kreasi.

\section{Arsip}

Proposal Panitia Pembangunan Gapura Barat" Manunggaling Karsa Gotro Wiworo II"Rw IIPawisman Gedangan Kemiri Kebakkramat Tahun 2009. 
Kabupaten Karanganyar Dalam Angka. Badan Pusat Statistik Kabupaten Karanganyar 2011

Kabupaten Karanganyar Dalam Angka. Badan Pusat Statistik Kabupaten Karanganyar 2016

\section{Media Online}

www.perpusnas.go.id diakses tanggal 29 Desember 2016 pukul 20.30 . http://afeministblog.blogspot.co.id/. Diunduh 11 Januari 2017 pukul 20.05 wib.

http://putrimuqodimatul.blogspot.co.id/ Diunduh 11 Januari 2017 pukul 20.15 wib.

http://www.pedharmanaryasukahet.org/) Diunduh 11 Januari 2017 pukul 20. 43 wib. 